\title{
Influence of Ventilation and Humidity During Storage on Weight and Quality Changes of White Yam Tubers (Dioscorea rotundata Poir), ${ }^{1}$
}

\begin{abstract}
Osi Mozie ${ }^{2}$
ABSTRACT

Maintaining at least $95 \%$ relative humidity in the ventilating air caused significantly less weight loss than ventilating with air at $85 \%$ relative humidity. In addition, significantly less shrivelling, and sprouting were found in tubers ventilated with air at $95 \%$ relative humidity. There was no difference between the two air humidities in the amount of rot found.

Intermittent ventilation allowed significantly less weight loss than continuous ventilation. Also intermittent ventilation caused significantly less shrivelling and less sprouting than continuous ventilation.
\end{abstract}

\section{INTRODUCTION}

Dioscorea rotundata Poir (white yam) a native of West Africa is grown on a greater acreage than any other yam species in the world (5). Although West Africa is the most important area in the world for white yam production its cultivation has also spread to other parts of the world including the West Indies, and to some extent, East Africa.

During storage in the conventional barn (fig. 1), which consists in tying tubers horizontally on vertical poles with overhead shading from direct rays of the sun, yam tubers experience serious loss of quality, reduced storage life or total loss through rotting. Considerable loss of moisture and carbohydrates (weight losses) may also occur (2). In principle, storage is possible as long as the tubers remain physiologically dormant. However, once dormancy is terminated and sprouting begins, the tubers senesce and can no longer be stored effectively (6). The seriousness of the problem of weight losses of yams in storage can be appreciated by considering that the average inhabitant of the African "yam zone" consumes between 0.5 to $1 \mathrm{~kg}$ of yam daily, which represents between 0.25 and 0.50 of his total caloric intake (1).

Not much significant advance has been made in the technological aspects of yam storing. As a result, quality change and weight loss during storage in the conventional barn have not been reduced. Yam tubers can only be stored from 3 to 4 months in the conventional barn, but after that time quality deteriorates and weight decreases.

${ }^{1}$ Manuscript submitted to Editorial Board, September 6, 1983.

${ }^{2}$ Department of Botany, University of Nigeria Nsukka. The author is grateful to the Senate Research Grant Committee of the University of Nigeria for financial assistance given to this project. The department of Crop Science of the University of Nigeria Nsukka permitted the use of their constant temperature growth chambers. 


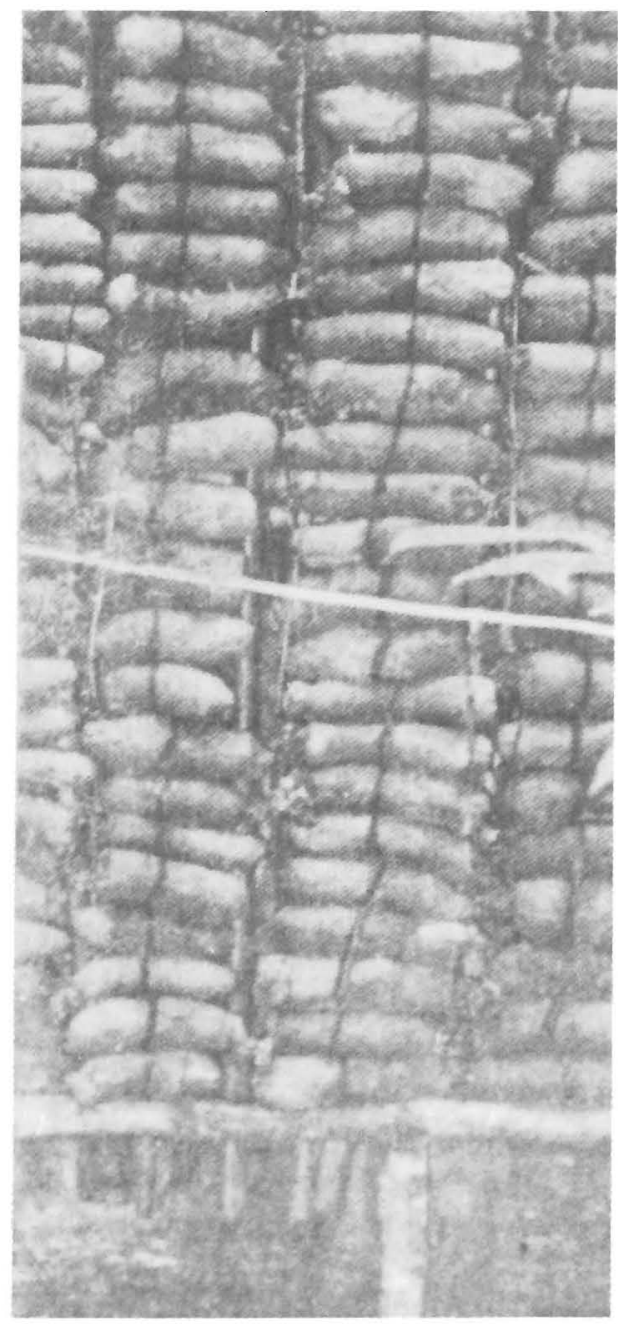

FIG. 1.-The conventional barn. Yams are tied horizontally on vertical poles with overhead shading from direct rays of the sun.

Previous studies (2) have revealed that certain relationships exist between the storage environment, storage management, length of the storage season and level of weight and quality changes that occur during storage. However, certain environmental factors such as ventilation and humidity were not completely evaluated in terms of their effects on either weight loss or quality change.

The data presented herein point out the interrelationships between the storage environment and weight and quality changes occurring to 
white yams throughout a 330-day storage period. The weight yam tubers lose during storage is influenced by a number of factors, such as amount of injury (4), presence of diseases, and rot. Also, the species of yams grown, the cultural and climatic conditions under which they were grown can have effect (3). However, for the purpose of this paper only the effects of the relative humidity of the ventilating air and continuous versus intermittent ventilation are considered.

The storage of white yam tubers must be considered from the standpoint of both the fresh and processing markets. The fresh market is concerned with their external appearance as well as their internal or cooking quality. The processing market is concerned with those tuber characteristics, whether external or internal which influence the quality of the processed product.

While it is true that a wide range of commercially interesting products can result from yam processing, the larger proportion of the resources in West African universities and research establishments has been engaged in the development of an instant yam flour of superior quality which will reconstitute upon mixing with hot water into pounded yam (fufu) of comparable quality and acceptance as traditional pounded yam. Certainly, the maintenance of a high-quality raw product for both the fresh and processing markets should be affected by the storage management and the environmental factors to which the tubers are subjected during storage. Therefore, such changes as rotting, shrivelling or sprouting are considered as quality defects.

\section{MATERIALS AND METHODS}

Dioscorea rotundata Poir (white yams) grown at the University of Nigeria Nsukka Botanical Garden were harvested, placed in constant temperature growth chambers in a research laboratory. Each of the chambers held $180 \mathrm{~kg}$ of yam tubers. The constant temperature growth chambers had a temperature variation of $\pm 1^{\circ} \mathrm{C}$ and an automatic light switch, 12 hour light alternating with 12 hour darkness throughout the experimental period. The temperature, humidity and flow of air in each storage chamber was controlled. The weight losses of the yam tubers were obtained by periodically weighing the tubers in each chamber collectively throughout the entire storage period. In each of 2 years, there were 4 pairs of storage chambers and in the other 2 years there were 6 pairs of storage chambers. The data reported herein are from experiments carried out for 4 crop years (1979, 1980, 1981 and 1982).

Two variations of ventilation management were used to control the temperature within the storage chambers-intermittent and continuous. When ventilated intermittently, the tubers in the storage chambers were supplied with air only as often and as long as was necessary to maintain 


\section{JOURNAL OF AGRICULTURE OF UNIVERSITY OF PUERTO RICO}

a uniform temperature of $16^{\circ} \mathrm{C}$, which has been reported as the ideal temperature to store Dioscorea rotundata for a full year without serious losses (7), whereas with continuous ventilation, air was supplied 24 hours a day, throughout the storage season at $16^{\circ} \mathrm{C}$.

Two variations in the relative humidity of the air in the storage chambers were used: 85 and $95 \%$. The proper relative humidity was maintained by operation of humidifiers in the storage growth chambers.

\section{RESULTS AND DISCUSSION}

Ventilating the tubers intermittently at the rate of about $0.3 \mathrm{~m}^{3}$ per minute per $100 \mathrm{~kg}$ showed significantly less weight loss than when the air was provided continuously (table 1). At the end of a 30-day period, the storage chambers ventilated continuously showed $0.68 \%$ more weight loss than comparable storage chambers receiving air of the same temperature and humidity intermittently. The storage chambers under continuous ventilation continued to lose weight more rapidly than those receiv-

TABLE 1.-Influence of ventilation during storage on the periodic weight loss of Dioscorea rotundata Poir (white yams); 4-year means

\begin{tabular}{lccccccccccc}
\hline \multirow{2}{*}{ Ventilation } & \multicolumn{10}{c}{ Days of storage and weight loss (\%) } \\
\cline { 2 - 13 } & 30 & 60 & 90 & 120 & 150 & 180 & \multicolumn{1}{c}{210} & 240 & \multicolumn{1}{c}{270} & \multicolumn{1}{c}{300} & 330 \\
\hline Intermittent & 2.38 & 3.80 & 4.92 & 5.70 & 6.58 & 7.56 & 8.60 & 9.90 & 11.52 & 13.22 & 15.68 \\
Continuous & 3.06 & 4.78 & 6.20 & 7.22 & 8.28 & 9.54 & 10.82 & 12.26 & 14.00 & 15.76 & 18.52 \\
LSD 0.05 & 0.26 & 0.25 & 0.37 & 0.49 & 0.54 & 0.57 & 0.68 & 0.74 & 0.84 & 0.73 & 0.60 \\
LSD 0.01 & n.s. ${ }^{1}$ & n.s. & n.s. & n.s. & n.s. & n.s. & n.s. & n.s. & n.s. & n.s. & 1.11 \\
\hline
\end{tabular}

${ }^{1}$ n.s. $=$ nonsignificant.

ing air intermittently, and at the end of the 330-day storage period had lost $2.84 \%$ more weight than under intermittent ventilation.

Maintaining a uniform temperature of $16^{\circ} \mathrm{C}$ with air at $95 \%$ relative humidity in the storage environment can significantly minimize the quality defects of rotting, shrivelling and sprouting, and could ensure the steady supply of high quality tubers for both the fresh and processing markets in the yam consuming areas of the world. But to achieve the least quality change, the air at $95 \%$ relative humidity must be supplied intermittently and not continuously. The quality change caused by this treatment was highly significantly less than that found in either of the ventilation treatments (intermittently or continuously) with air at $85 \%$ relative humidity at similar storage temperature of $16^{\circ} \mathrm{C}$. The 4-year data show that when the relative humidity of the ventilating air was at least $95 \%$, weight losses were significantly less than with $85 \%$ (table 2). After 30-day storage, weight loss from the tubers receiving air at $85 \%$ r.h. was $3.40 \%$, whereas tubers receiving air at $95 \%$ r.h. or more had lost 
only $2.04 \%$. After 60 -day storage with air at $85 \%$ r.h. there was $5.42 \%$ weight loss, and with $95 \%$ r.h., there was only $3.14 \%$. In each case these differences were highly significant.

The tubers ventilated with air at $85 \%$ relative humidity continued to lose weight more rapidly throughout the entire storage period than did those that received air at $95 \%$. After 330-day storage, weight loss at $85 \%$ relative humidity was $19.90 \%$, and at $95 \%$ relative humidity only $14.28 \%$. This is a highly significant difference.

The least weight loss occurred when the tubers were ventilated intermittently with air of at least $95 \%$ relative humidity (table 3 ). After 30 days of storage, yams in the storage chambers receiving intermittent ventilation at $95 \%$ relative humidity lost $1.88 \%$ of their original weight, and in the chambers receiving continuous ventilation at $95 \%$ relative humidity yams lost $2.20 \%$, a nonsignificant difference. However, intermittent ventilation at $85 \%$ caused an average weight loss of $2.88 \%$ and continuous ventilation at $85 \%$ lost an average weight of $3.92 \%$. These

TABLE 2.-The influence of humidity during storage on the periodic weight loss of

Dioscorea rotundata (white yams); 4-year means

\begin{tabular}{lrrrrrrrrrrrr}
\hline \multirow{2}{*}{$\begin{array}{c}\text { Relative } \\
\text { humidity }\end{array}$} & \multicolumn{10}{c}{ Days of storage and weight loss (\%) } \\
\cline { 2 - 13 } & 30 & 60 & 90 & 120 & 150 & 180 & 210 & 240 & 270 & 300 & 330 \\
\hline$\%$ & & & & & & & & & & & \\
95 & 2.04 & 3.14 & 5.56 & 4.88 & 5.60 & 6.44 & 7.28 & 8.48 & 10.06 & 11.72 & 14.28 \\
85 & 3.40 & 5.42 & 6.90 & 8.04 & 9.20 & 10.66 & 12.14 & 13.68 & 15.44 & 17.28 & 19.90 \\
LSD 0.05 & 0.26 & 0.25 & 0.37 & 0.49 & 0.54 & 0.57 & 0.68 & 0.74 & 0.84 & 0.73 & 0.60 \\
LSD 0.01 & 0.48 & 0.45 & 0.68 & 0.90 & 1.04 & 1.04 & 1.24 & 1.35 & 1.54 & 1.35 & 1.11 \\
\hline
\end{tabular}

losses are significantly higher than those from the storage chamber ventilated intermittently with air of at least $95 \%$.

After 90 days of storage, each treatment was significantly different from the other. Intermittent ventilation with air at $95 \%$ relative humidity caused significantly less weight loss than any other treatment. In turn, continuous ventilation with air at $95 \%$ caused significantly less weight loss than did intermittent or continuous ventilation with air at $85 \%$.

The weight losses from the various treatments continued to diverge throughout storage, and after 330 days each treatment was still significantly different from each other treatment. Intermittent ventilation with $95 \%$ caused $12.76 \%$ weight loss, continuous ventilation with $95 \%$ caused $15.8 \%$ weight loss, intermittent ventilation with $85 \%$ caused $18.6 \%$ weight loss, and continuous ventilation with $85 \%$ caused $21.22 \%$ weight loss.

The data obtained during this study show that after 330 days of storage, there was no significant difference in the percentage of rotten tubers, 
TABLE 3.-The influence of ventilation and relative humidity during storage on the periodic weight loss of Dioscorea rotundata Poir (white yams); 4-year means

\begin{tabular}{|c|c|c|c|c|c|c|c|c|c|c|c|c|}
\hline \multirow{2}{*}{$\begin{array}{l}\text { Relative } \\
\text { humidity }\end{array}$} & \multirow{2}{*}{$\begin{array}{l}\text { Ventilation } \\
\text { management }\end{array}$} & \multicolumn{11}{|c|}{ Days of storage and weight loss $(\%)$} \\
\hline & & 30 & 60 & 90 & 120 & 150 & 180 & 210 & 240 & 270 & 300 & 330 \\
\hline 95 & Intermittent & 1.88 & 2.82 & 3.70 & 4.22 & 4.86 & 5.56 & 6.24 & 7.34 & 8.84 & 10.48 & 12.76 \\
\hline 95 & Continuous & 2.20 & 3.48 & 4.72 & 5.54 & 6.34 & 7.32 & 8.30 & 9.60 & 11.28 & 12.96 & 15.80 \\
\hline 85 & Intermittent & 2,88 & 4.76 & 6.14 & 7.18 & 8.30 & 9.56 & 10.94 & 12.44 & 14.20 & 15.98 & 18.60 \\
\hline 85 & Continuous & 3.92 & 6.10 & 7.68 & 8.90 & 10.22 & 11.78 & 13.34 & 14.90 & 16.68 & 18.56 & 21.22 \\
\hline LSD & 0.05 & 0.34 & 0.38 & 0.36 & 0.35 & 0.36 & 0.36 & 0.42 & 0.47 & 0.52 & 0.62 & 1.22 \\
\hline LSD & 0.01 & 0.51 & 0.57 & 0.54 & 0.53 & 0.54 & 0.55 & 0.64 & 0.71 & 0.78 & 0.94 & 1.85 \\
\hline
\end{tabular}


TABLE 4.- The influence of ventilation during storage on the quality changes of

Dioscorea rotundata (white yams) after 330 days of storage; 4-year means

\begin{tabular}{lcccccc}
\hline $\begin{array}{c}\text { Ventilation } \\
\text { management }\end{array}$ & Rotten & Shrivelled & Sprouted & $\begin{array}{c}\text { Total } \\
\text { quality } \\
\text { faults }\end{array}$ & $\begin{array}{c}\text { Weight } \\
\text { loss }\end{array}$ & $\begin{array}{c}\text { Total } \\
\text { loss }\end{array}$ \\
\hline Intermittent & $\%$ & $\%$ & $\%$ & $\%$ & $\%$ & $\%$ \\
Continuous & 3.54 & 4.30 & 4.60 & 12.44 & 15.68 & 28.12 \\
LSD 0.05 & 3.92 & 5.44 & 6.18 & 15.54 & 18.52 & 34.06 \\
LSD 0.01 & n.s. ${ }^{1}$ & n.s & n.s & 2.56 & 0.60 & 3.05 \\
\hline
\end{tabular}

${ }^{1}$ n.s. = nonsignificant.

TABLE 5.-The influence of humidity during storage on the quality changes of Dioscorea rotundata Poir (white yams) after 330 days of storage; 4-year means

\begin{tabular}{ccccccc}
\hline $\begin{array}{c}\text { Relative } \\
\text { humidity }\end{array}$ & Rotten & Shrivelled & Sprouted & $\begin{array}{c}\text { Total } \\
\text { quality } \\
\text { faults }\end{array}$ & $\begin{array}{c}\text { Weight } \\
\text { loss }\end{array}$ & $\begin{array}{c}\text { Total } \\
\text { loss }\end{array}$ \\
\hline$\%$ & $\%$ & $\%$ & $\%$ & $\%$ & $\%$ & $\%$ \\
95 & 3.94 & 2.24 & 3.84 & 10.02 & 14.28 & 24.30 \\
85 & 3.52 & 7.58 & 6.94 & 18.04 & 19.90 & 37.94 \\
LSD 0.05 & n.s. ${ }^{1}$ & 1.25 & 0.94 & 2.56 & 0.60 & 3.05 \\
LSD 0.01 & n.s. & 2.30 & n.s. & 4.72 & 1.11 & 5.59 \\
\hline
\end{tabular}

${ }^{1}$ n.s. = nonsignificant.

TABLE 6.-The influence of ventilation and relative humidity during storage on the quality of changes of Dioscorea rotundata Poir (white yams) after 330 days of storage; 4-year means

\begin{tabular}{cccccccc}
\hline $\begin{array}{c}\text { Relative } \\
\text { humidity }\end{array}$ & $\begin{array}{c}\text { Ventilation } \\
\text { management }\end{array}$ & Rotten & Shrivelled & Sprouted & $\begin{array}{c}\text { Total } \\
\text { quality } \\
\text { faults }\end{array}$ & $\begin{array}{c}\text { Weight } \\
\text { loss }\end{array}$ & $\begin{array}{c}\text { Total } \\
\text { loss }\end{array}$ \\
\hline$\%$ & & $\%$ & $\%$ & $\%$ & $\%$ & $\%$ & $\%$ \\
95 & Intermittent & 3.98 & 1.68 & 3.32 & 8.98 & 12.72 & 21.7 \\
95 & Continuous & 3.88 & 2.80 & 4.36 & 11.04 & 15.80 & 26.84 \\
85 & Intermittent & 3.08 & 6.94 & 5.88 & 15.90 & 18.60 & 34.5 \\
85 & Continuous & 3.96 & 8.22 & 8.00 & 20.18 & 21.22 & 41.40 \\
LSD 0.05 & & n.s. ${ }^{1}$ & 1.78 & 1.69 & 5.74 & 1.22 & 5.82 \\
LSD 0.01 & & n.s. & 2.69 & n.s. & 8.69 & 1.85 & 8.81 \\
\hline
\end{tabular}

${ }^{1} \mathrm{n} . \mathrm{s} .=$ nonsignificant.

shrivelled tubers, and sprouted tubers, regardless of the method of supplying air (table 4).

There was no significant difference in rot between tubers ventilated with air at $95 \%$ relative humidity and those ventilated with air at $85 \%$ (table 5). There were significantly fewer shrivelled and sprouted tubers when they were maintained at $16^{\circ} \mathrm{C}$ with air at $95 \%$ relative humidity than when they received air at $85 \%$. The $18.04 \%$ total grade defects found in tubers ventilated with air of $85 \%$ relative humidity was signifi- 
cantly higher than the $10.02 \%$ defects found in tubers ventilated with air at $95 \%$.

The least quality change occurred when air at least $95 \%$ relative humidity was supplied intermittently (table 6 ). The $8.98 \%$ quality change caused by this treatment was highly significantly less than that found in either of the treatments ventilated with air of $85 \%$.

\section{RESUMEN}

En ñames almacenados la ventilación con aire a por lo menos 95\% de humedad relativa disminuyó significativamente la merma en peso sobre la ventilación con aire a $85 \%$. También se arrugaron y brotaron significativamente menos a $95 \%$ de humedad relativa. No hubo diferencia entre los dos porcentajes de humedad con relación a la pudrición.

Con la ventilación intermitente hubo menos merma en peso, menos arrugamiento y menos brotación que con la ventilación continua.

\section{LITERATURE CITED}

1. Ayensu, E. S. and Coursey, D. C., 1972. Guinea yams; botany ethnobotany, use and possible future of yams in West Africa, Economic Botany, 26 (4): 301-18.

2. Coursey, D. G., 1961. The magnitude and origin of storage losses in Nigerian yams, $J$ Sci. Fd Agric. 12: 574-80.

3. - 1963. Storage losses in yams, Niger. Grower and Prod. 2 (3): 43-5.

4. Martin, F. W., 1974. Effects of type of wound, species and humidity on curing of yam (Dioscorea alata L.) tubers before storage, J. Agric. Univ. P.R. 58: 211-18.

5. Onwueme, I. C., 1978. The Tropical Tuber Crops, John Wiley \& Sons Ltd., New York.

6. Passam, H. C. and Noon, R. A., 1977. Deterioration of yams and cassava during storage, Ann. Appl. Biol. 85: 436-40.

7. Rivera, J. R., González, M. A., Collazo de Rivera, A. and Cuevas-Ruiz, J., 1974. An improved method for storing yam (Dioscorea alata), J. Agric. Univ. P.R. 58: 456-65. 